\title{
THE EFFECT OF COMPETENCY ON CIVIL SERVANTS PERFORMANCE IN THE HEALTH SERVICE OF PEKANBARU CITY
}

\author{
${ }^{1}$ Herman, ${ }^{2}$ Eka Sri Hardini \\ ${ }^{12}$ Sekolah Tinggi Ilmu Ekonomi Riau \\ E-mail: hermanrupat83@gmail.com
}

\begin{abstract}
In order to improve the quality and quantity of performance of Civil Servants (PNS) at the Pekanbaru City Health Office, it is necessary to conduct Competency research for all Civil Servants (PNS) of the Pekanbaru City Health Office. This competency is carried out so that office holders can occupy their positions in accordance with their educational qualifications, skills/ experience and attitudes. In general, the purpose of this study is to determine the effect of competence on employee performance at the Pekanbaru City Health Office. The number of samples in this study were 91 employees. In the overall validity test the statement of competence and performance variables are declared valid because the $r_{\text {count }}>r_{\text {table }}(0.206)$ is obtained. Simple linear regression results obtained by the value of $Y=2.729+0.899 X$. From the partial test results or t test obtained value of $t_{\text {count }}(6.928)>$ $t_{\text {table }}(1.986)$ with a sig level of $0.000<0.05$ which means that competence has a significant effect on performance. The coefficient of determination test results $\left(R^{2}\right)$ of 0.350 or $35 \%$, meaning that the magnitude of the influence or contribution given by the competency variable to the performance variable is $35 \%$ while the remaining $65 \%$ is influenced by other factors not examined in this study.
\end{abstract}

Keywords: Competence, Performance

\section{A. PENDAhUluan}

Bangsa Indonesia dalam era pembangunan saat ini dihadapkan pada berbagai tantangan masa depan serta masalah yang tidak hanya terbatas pada proses perubahan struktur ekonomi dan sosial yang cepat, tanpa batas. Salah satu masalah yang dihadapi oleh bangsa Indonesia adalah mengenai kualitas sumberdaya manusia (SDM). Sumber daya manusia (SDM) merupakan salah satu factor penting dalam pembangunan. Pengembangan SDM pada intinya diarahkan dalam rangka meningkatkan kualitasnya yg pada akhirnya akan dapat meningkatkan produktivitasnya.

Hasil dari berbagai studi menunjukkan bahwa kualitas SDM merupakan factor penentu produktivitas baik secara makro maupun mikro. Secara makro adalah suatu proses peningkatan kualitas atau kemampuan manusia dalam rangka mencapai tujuan pembangunan bangsa. Proses peningkatan disini mencakup perencanaan pengembangan dan pengelolaan sumber daya manusia.

Secara mikro, dalam arti lingkungan unit kerja (departemen atau organisasi yang lain), maka sumber daya manusia adalah: tenaga kerja atau pegawai didalam suatu organisasi, yang mempunyai peran penting dalam mencapai keberhasilan. Fasilitas yang canggih dan lengkap belum merupakan jaminan akan keberhasilan suatu organisasi tanpa diimbangi oleh kualitas manusia yang akan memanfaatkan fasilitas tersebut, (Sedarmayanti, 2016).

Sumberdaya manusia merupakan hal yang sangat penting dan mempunyai peranan yang sangat besar karena SDM adalah ilmu dan seni mengatur dan peran hubungan kerja agar dapat secara efektif dalam rangka membantu mewujudkan tujuan perusahaan, karyawan dan masyarakat.

Permasalahan Pegawai Negeri Sipil (PNS) dalam birokrasi pemerintah adalah berkenaan dengan sumber daya manusia. Sumber daya manusia yang dimaksud adalah Pegawai Negeri Sipil (PNS) yang ditempatkan dan bekerja dilingkungan birokrasi, untuk menjalankan tugas pokok dan fungsi sebagaimana yang telah ditetapkan.

Undang-Undang Nomor 43 Tahun 1999, menjelaskan bahwa pengangkatan Pegawai Negeri Sipil (PNS) dalam jabatan dilaksanakan berdasarkan prinsip profesionalisme sesuai dengan kompetensi yang ditetapkan untuk jabatan itu serta syarat objektif lainnya tanpa membedakan jenis kelamin, suku, agama, ras atau golongan.

Permasalahan yang terjadi Pada Dinas Kesehatan Kota Pekanbaru yaitu para 
pegawai belum sepenuhnya menyadari tujuan dari pengembangan pegawai, hal ini dapat dilihat dari masih adanya pegawai yang memillki kualitas pendidikan yang rendah dan kurang cocoknya jenis pekerjaan dengan keahlian yang dimiliki oleh pegawai serta kesalahan penempatan dan penyebaran pegawai pada setiap unit kerja yang kurang seimbang dan adanya pegawai yang tidak mengikuti program pengembangan pegawai yaitu melalui pendidikan dan pelatihan yang telah diberikan oleh Dinas Kesehatan Kota Pekanbaru.

Dinas Kesehatan Kota Pekanbaru sebagai suatu instansi pemerintahan kota yang berhubungan langsung dalam meningkatkan kesehatan yang ada di kota Pekanbaru, dalam perannya Dinas Kesehatan Kota Pekanbaru mempunyai tugas penting dalam meningkatkan kualitas kesehatan masyarakat Kota Pekanbaru. Oleh, karena itu pegawai Dinas Kesehatan Kota Pekanbaru hendaknya dapat meningkatkan kinerjanya agar kualitas Kesehatan masyarakat Kota Pekanbaru dari tahun ke tahun terus meningkat.

Dalam rangka peningkatan kualitas dan kuantitas kinerja Pegawai Negeri Sipil (PNS) pada Dinas Kesehatan Kota Pekanbaru maka perlu dilakukan penelitian Kompetensi bagi semua Pegawai Negeri Sipil (PNS) Dinas Kesehatan Kota Pekanbaru. Kompetensi ini dilakukan agar pemangku jabatan dapat menduduki jabatannya sesuai dengan kualifikasi pendidikan, Keterampilan /pengalaman dan sikap yang dimilikinya.

Untuk itu Pegawai Negeri Sipil (PNS) selayaknya memiliki ketiga komponen tersebut, kompetensi pengetahuan yang menekankan pada kemampuan konsepsional yakni kerja yang banyak menggunakan pikiran, kompetensi pengetahuan merujuk pada kemampuan memahami keseluruhan organisasi secara utuh, bagaimana relasi antar organisasi, bagaimana perubahan pada salah satu bagian mempengaruhi keseluruhan proses, termasuk di dalamnya mampu memahami perubahan lingkungan organisasi, kemampuan merumuskan kebijakan yang Volume 11, Nomor 3, 27 September 2020 harus dilaksanakan staf serta kemampuan merumuskan kembali visi, misi dan tujuan organisasinya dengan membuat strategi perencanaan.

Kompetensi merupakan kemampuan seseorang dalam memahami bagaimana mewujudkan kebijakan, keputusan yang dibuat oleh pimpinan organisasi menjadi kenyataan atau dengan kata lain kompetensi keterampilan merupakan kemampuan mengimplementasikan kebijakan dengan menggunakan sumberdaya yang ada (man, machine and financial).

Kompetensi sikap/perilaku merupakan kemampuan menerjemahkan konsep yang dirumuskan oleh pimpinan (mengintegrasikan kebijakan), serta menghimpun informasi dari anggota organisasi dan mengolahnya menjadi rekomendasi kebijakan yang dapat dijadikan sebagai pedoman bagi pimpinan di atasnya untuk membuat kebijakan. Kompetensi perilaku juga terikat dengan integritas dan komitmen pejabat untuk melaksanakan tanggungjawab secara professional.

Untuk mengukur kompetensi (kemampuan) Pegawai Negeri Sipil (PNS) maka indikator- indikator yang digunakan adalah : (1) Ratio jumlah pegawai , (2) Masa kerja pegawai, (3) Pendidikan formal yang dicapai, (4) Pendidikan dan Pelatihan (diklat). yang kesemuanya berkisar pada kualitas dan kuantitas pegawai.

Untuk mengetahui jumlah Pegawai Negeri Sipil pada Dinas Kesehatan Kota Pekanbaru, dapat dilihat dari tabel berikut ini

Tabel 1 Jumlah Pegawai Negeri Sipil pada Dinas Kesehatan Kota Pekanbaru Tahun 2014-2018

\begin{tabular}{|c|c|c|}
\hline Tahun & Jumlah PNS & Persentase Perkembangan PNS (\%) \\
\hline 2014 & 97 & $19.76 \%$ \\
\hline 2015 & 96 & $19.55 \%$ \\
\hline 2016 & 104 & $21.18 \%$ \\
\hline 2017 & 102 & $20.77 \%$ \\
\hline 2018 & 92 & $18.74 \%$ \\
\hline
\end{tabular}

Berdasarkan tabel 1 diatas dapat dijelaskan bahwa Pegawai Negeri Sipil yang bekerja pada Dinas Kesehatan Kota

P.ISSN: $1410-7988 \quad$ E.ISSN: $2614-123 X$ 
Pekanbaru pada tahun 2014 sebanyak 97 orang (19.76\%), tahun 2015 sebanyak 96 orang $(19.55 \%)$, tahun 2016 sebanyak 104 $(21.18 \%)$, tahun 2017 sebanyak 102 orang (20.77\%), dan tahun 2018 sebanyak 92 orang $(18.74 \%)$.

Kinerja pegawai perlu dilakukan penilaian agar setiap pegawai mempunyai standar penilaian dan melakukan perubahan ke arah yang lebih baik. Maka disusunlah Sasaran Kerja Pegawai (SKP) berdasarkan Peraturan Pemerintah Republik Indonesia Nomor 46 Tahun 2011 tentang penilaian prestasi kerja Pegawai Negeri Sipil, maka dapat dilihat bahwa penilaian yang diberikan kepada pegawai berdasarkan aspek Orientasi Pelayanan, Integritas, Komitmen, Disiplin, kerja sama masih belum maksimal. Bahwa kriteria penialai pegawai negeri sipil tertuang pada peraturan pemerintah Republik Indonesia No 46 Tahun 2011 pasal 17, nilai prestasi kerja PNS dinyatakan dengan angka dan sebutan sebagai berikut;
1. $91 \mathrm{ke}$ atas
: sangat baik
2. $76-90$
: baik
3. $61-75$
: cukup
4. $51-60$
: kurang
5. 50 ke bawah : buruk

Selanjutnya, penelitian terhadap kinerja pegawai Dinas Kesehatan Kota Pekanbaru Kota Pekanbaru dapat dilihat pada tabel berikut ini

\begin{tabular}{l} 
Tabel 2 Penilaian Rata-rata Pelaksanaan \\
Kinerja Pegawai Negeri Sipil Dinas \\
Kesehatan Kota Pekanbaru Tahun 2014- \\
\begin{tabular}{|c|c|c|}
\hline \multicolumn{3}{|c|}{2018} \\
\hline Tahun & Jumlah Pegawai & $\begin{array}{c}\text { Nilai Rata-rata } \\
\text { SKP }\end{array}$ \\
\hline 2014 & 97 & 82.50 \\
\hline 2015 & 96 & 83.00 \\
\hline 2016 & 104 & 84.50 \\
\hline 2017 & 102 & 83.50 \\
\hline 2018 & 92 & 83.75 \\
\hline
\end{tabular} \\
\hline
\end{tabular}

Berdasarkan tabel 2 diatas dapat dijelaskan bahwa nilai rata-rata Sasaran Kinerja Pegawai Negeri Sipil pada Dinas Kesehatan Kota Pekanbaru adalah baik. Jika dilihat dari latar belakang pendidikan yang dimiliki pegawai pada Kantor Dinas Kesehatan Kota Pekanbaru, maka dapat

Eko dan Bisnis (Riau Economics and Business Reviewe) Volume 11, Nomor 3, 27 September 2020 dikatakan cukup baik karena melihat situasi dan kondisi sosial, ekonomi serta persoalan yang terjadi pada masyarakat saat ini sangat kompleks, sehingga sangat diperlukan upaya- upaya untuk memberikan pendidikan dan pelatihan kepada mereka agar dapat bekerja lebih optimal didalam menjalankan roda pemerintahan. Dari penilaian prestasi kerja pegawai negeri sipil tersebut ada 2 unsur yang dinilai yaitu : unsur realisasi kegiatan dan perilaku (orientasi pelayanan, integritas, komitmen, disiplin, kerjasama dan kepemimpinan)

Tabel 3 Jenjang Pendidikan Pegawai Negeri Sipil pada Dinas Kesehatan Kota Pekanbaru Tahun 2018

\begin{tabular}{|c|c|c|c|}
\hline No & Jenjang Pendidikan & Jumlah & Persentase (\%) \\
\hline 1 & S.2 & 10 & $10.87 \%$ \\
\hline 2 & S.1 & 56 & $60.87 \%$ \\
\hline 3 & D.IV & 1 & $1.09 \%$ \\
\hline 4 & D.III & 19 & $20.65 \%$ \\
\hline 5 & D.I & 2 & $2.17 \%$ \\
\hline 6 & SMA Sederajat & 4 & $4.35 \%$ \\
\hline \multicolumn{2}{r|}{ TOTAL } & $\mathbf{9 2}$ & $\mathbf{1 0 0}$ \\
\hline
\end{tabular}

Berdasarkan tabel 3 diatas dapat dijelaskan bahwa latar belakang pendidikan Pegawai Negeri Sipil pada Dinas Kesehatan Kota Pekanbaru yakni S.2 berjumlah 10 orang $(10.87 \%)$, selanjutnya S.1 berjumlah 56 orang (60.87\%), D.IV berjumlah 1 orang (1.09 \%), D.III berjumlah 19 orang $(20.65 \%)$, D.I berjumlah 2 orang $(2.17 \%)$ dan SMA Sederajat berjumlah 4 orang $(4.35 \%)$. Jenjang pendidikan ini tentu berimplikasi pada kinerja serta pemahaman atas pekerjaan yang dijalankan oleh pegawai yang bersangkutan.

Tabel 4 Data Realisasi Hasil Pelaksanaan kegiatan Dinas Kesehatan Kota Pekanbaru Tahun 2014-2018

\begin{tabular}{|c|c|c|c|c|c|}
\hline Tahun & $\begin{array}{c}\text { Jumlah } \\
\text { Kegiatan }\end{array}$ & \multicolumn{2}{|c|}{ Realisasi Kegiatan } & $\begin{array}{c}\text { Persentase } \\
\text { Capaian } \\
\text { Kegiatan }\end{array}$ & $\begin{array}{c}\text { Persentase } \\
\text { Tidak } \\
\text { Tercapainya } \\
\text { Kegiatan }\end{array}$ \\
& Tercapai & $\begin{array}{c}\text { Tidak } \\
\text { Tercapai }\end{array}$ & & 40.74 \\
\hline 2014 & 81 & 48 & 33 & 59.26 & 42.42 \\
\hline 2015 & 66 & 38 & 28 & 57.58 & 43.42 \\
\hline 2016 & 76 & 43 & 33 & 56.58 & 38.10 \\
\hline 2017 & 84 & 52 & 32 & 61.90 & 40.82 \\
\hline 2018 & 98 & 58 & 40 & 59.18 & 40 \\
\hline
\end{tabular}

Berdasarkan tabel 4 diatas dapat dijelaskan bahwa tahun 2014 persentase P.ISSN: 1410-7988

E.ISSN: 2614-123X 
capaian kegiatan sebesar $59.26 \%$ dari 81 kegiatan yang direncanakan penyelesaiannya, tahun 2015 persentase capaian kegiatan sebesar $57.58 \%$ dari 66 kegiatan yang direncanakan penyelesaiannya, tahun 2016 persentase capaian kegiatan sebesar $56.58 \%$ dari 76 kegiatan yang direncanakan penyelesaiannya, tahun 2017 persentase capaian kegiatan sebesar $61.90 .26 \%$ dari 84 kegiatan yang direncanakan penyelesaiannya, dan tahun 2018 persentase capaian kegiatan sebesar $59.18 \%$ dari 98 kegiatan yang direncanakan penyelesaiannya. Dari tahun 2014 sampai dengan tahun 2018 setiang kegiaan yang direncanakan belum mencapai angka $100 \%$ dalam pencapaian penyelesaiannya.

\section{Tinjauan Pustaka \\ Pengertian Manajemen}

Istilah manajemen (management) telah diartikan oleh berbagai pihak dengan perspektif yang berbeda. Misalnya, pengelolaan, pembinaan, pengurusan, ketatalaksanaan, kepemimpinan, pemimpin, ketatapengurusan, adminsitrasi, dan sebagainya. Manajemen adalah suatu proses pengarahan dan pemberian fasilitas kerja kepada orang yang diorganisasikan dalam kelompok formal untuk mencapai tujuan, (Jhon D. Millett dalam Siswanto, 2015: 1).

Supomo (2018: 1) istilah manajemen mengandung tiga pengertian, yaitu diantaranya adalah :

1. Manajemen sebagai suatu proses.

2. Manajemen sebagai kolektivitas orangorang yang melakukan aktivitas manajemen.

3. Manajemen sebagai salah satu seni dan sebagai suatu seni.

Sedarmayanti (2017: 37) manajemen sumber daya manusia adalah kebijakan dan praktik menentukan aspek "manusia" atau sumber daya manusia dalam posisi manajemen, termasuk merekrut, menyaring, melatih, member penghargaan, dan penilaian.

Arifin dan Muhammad (2016: 2) manajemen adalah sebagai proses perencanaan, pengorganisasian, pengarahan, dan pengawasan usaha-usaha para anggota

Eko dan Bisnis (Riau Economics and Business Reviewe) Volume 11, Nomor 3, 27 September 2020 organisasi dan penggunaan sumber daya organisasi lainnya agar mencapai tujuan organisasi yang telah ditetapkan.

Feriyanto dan Triana (2015: 4) manajemen adalah suatu proses penyelenggaraan berbagai kegiatan dalam rangka penerapan tujuan dan sebagai kemampuan atau keterampilan orang yang menduduki jabatan manajerial untuk memperoleh sesuatu hasil dalam rangka pencapaian tujuan melalui kegiatankegiatan orang lain.

\section{Manajemen Sumber Daya Manusia}

Noe dalam Kasmir (2016: 6) manajemen sumber daya manusia merupakan bagaimana mempengaruhi perilaku, sikap dan kinerja karyawan melalui kebijakan dan sistem yang dimiliki perusahaan.

Supomo (2018: 4) manajemen sumber daya manusia adalah ilmu dan seni yang mengatur peranan tenaga kerja (man) yang terdapat pada organisasi agar efektif dan efisien demi terwujudnya suatu tujuan.

Rivai dalam Suwatno dan Priansa (2018: 29) manajemen sumber daya manusia merupakan satu bidang dari manajemen umum yang meliputi segi-segi perencanaan, pengorganisasian, pelaksanaan, dan pengendalian.

Menurut Sedarmayanti (2017: 11) manajemen sumber daya manusia adalah suatu proses pemanfaatan SDM secara efektif dan efisien melalui kegiatan perencanaan, penggerakan, dan pengendalian semua nilai yang menjadi kekuatan manusia untuk mencapai tujuan.

Edison, Anwar, dan Komariyah (2016: 10) manajemen sumber daya manusia adalah manajemen yang memfokuskan diri memaksimalkan kemampuan karyawan atau anggotanya melalui berbagai langkah strategis dalam rangka meningkatkan kinerja pegawai/ karyawan menuju pengoptimalan tujuan organisasi.

Flippo dalam Priansa (2016: 21) menyatakan bahwa manajemen sumber daya manusia adalah perencanaan,

\footnotetext{
P.ISSN: 1410-7988 E.ISSN: 2614-123X
} 
pengorganisasian, pengendalian pengembangan, pengarahan dan dari pengadaan, kompensasi,

pengintegrasian, pemeliharaan, dan pemberhentian pegawai, dengan maksud terwujudnya tujuan perusahaan individu, pegawai, dan masyarakat.

Manullang (2015: 198) manajemen sumber daya manusia adalah seni dan ilmu pengadaan, pengembangan, dan pemanfaatan sumber daya manusia sehingga tujuan organisasi direalisasi secara daya guna dan adanya kegairahaan kerja dari semua tenaga kerja.

Menurut Dessler dalam Widodo (2015: 2) manajemen sumber daya manusia adalah proses memperoleh, melatih, menilai, dan memberikan kompensasi kepada karyawan, memperhatikan hubungan kerja mereka, kesehatan, keamanan, dan masalah keadilan.

\section{Fungsi Manajemen Sumber Daya Manusia}

Kasmir (2016: 14) dalam praktiknya fungsi manajemen sumber daya manusia terdiri dari :

1. Analisis Jabatan (Job Analysis)

2. Perencanaan Sumber Daya Manusia (Human Resource Planning)

3. Penarikan Pegawai (Recruitment)

4. Seleksi (Selection)

5. Pelatihan dan Pengembangan (Training and Development)

6. Evaluasi Kinerja (Performance Evaluation)

7. Kompensasi (Compensation)

8. Jenjang Karier (Career Path)

9. Keselamatan dan Kesehatan (Safety and Health)

10. Hubungan Industrial (Industrial Relation)

11. Pemutusan Hubungan Kerja
(Separation)

Menurut Flippo dalam Suwatno dan Priansa (2018: 30) menguraikan fungsi manajemen sumber daya manusia adalah sebagai berikut :

\section{Fungsi Manajerial}

Eko dan Bisnis (Riau Economics and Business Reviewe) Volume 11, Nomor 3, 27 September 2020
1) Perencanaan, suatu proses penentuan tindakan untuk mencapai tujuan.

2) Pengorganisasian, dalam pengorganisasian dibentuk suatu struktur organisasi dan dalam struktur ini nantinya ditunjukkan bagaimana hubungan antara satu unit dengan unit lainnya.

3) Pengarahan, berarti memeberi petunjuk dan mengajak para pegawai agar mereka berkemauan secara sadar untuk melaksanakan pekerjaan sesuai dengan yang telah ditentukan perusahaan.

4) Pengendalian, berarti melihat, mengamati, dan menilai tindakan atau pekerjaan pegawai, apakah mereka benar-benar melaksanakan pekerjaan sesuai dengan rencana.

2. Fungsi Operatif atau Fungsi Teknis

1) Pengadaan (Recruitment), memperoleh jumlah dan jenis pegawai yang tepat untuk mencapai tujuan organisasi, fungsi ini terutama berkaitan dengan penentuan kebutuhan pegawai dan penarikannya seleksi dan penempatannya.

2) Pengembangan (Development), pengembangan dilakukan dengan tujuan untuk meningkatkan keterampilan melalui latihan yang diperlukan untuk dapat menjalankan pekerjaan dengan baik.

3) Pengintegrasian (Integration), adalah penyesuain sikap-sikap, keinginan pegawai, dengan keinginan perusahaan dengan masyarakat.

4) Pemeliharaan (Maintenance), berarti berusaha untuk mempertahankan dan meningkatkan kondisi yang telah ada.

5) Pensiun (Separation), berhubungan dengan pegawai yang sudah lama bekerja pada perusahaan.

\section{Kompetensi}

Pengertian Kompetensi

P.ISSN: 1410-7988

E.ISSN: 2614-123X 
Peraturan pemerintah No. 101 Tahun 2000 (pasal 3) kompetensi adalah kemampuan dan karakteristik yang dimiliki oleh seorang pegawai negeri sipil berupa pengetahuan, sikap perilaku yang diperlukan dalam tugas dan jabatannya, (Sutrisno, 2011: 203).

Menurut Edison, Anwar, dan Komariah dalam Teguh (2018: 226) kompetensi adalah kemampuan individu untuk melaksanakan suatu pekerjaan dengan benar dan memiliki keunggulan yang didasarkan pada hal-hal yang menyangkut pada pengetahuan (Knowledge), keahlian (skill), dan sikap (attitude).

Menurut Spencer and Spencer dalam Sedarmayanti (2017: 20) kompetensi adalah bagian dari kepribadian yang mendalam dan melekat pada seseorang, serta perilaku yang dapat diprediksi pada berbagai keadaan dan tugas pekerjaan.

Priansa (2016: 254) kompetensi adalah peta kapasitas pegawai atas atribut pekerjaan yang diembannya yang merupakan kumpulan dari kemampuan, keterampilan, kematangan, pengalaman, kefektifan, keefisienan, dan kesuksesan dalam mengemban tanggung jawab pekerjaan.

\section{Tipe Kompetensi}

Menurut Priansa (2016: 256) ada beberapa tipe kompetensi yang pada umumnya dikenal dalam lingkungan organisasi maupun individu, yakni ;

1. Kompetensi perencanaan. Yang berkaitan dengan penetapan tujuan, menilai resiko, dan mengembangkan urutan tindakan dalam rangka mencapai tujuan organisasi.

2. Kompetensi mempengaruhi. Berkaitan dengan pengaruh yang diberikan kepada pegawai yang ada dalam organisasi, baik pegawai dalam level staf maupun manejerial.

3. Kompetensi berkomunikasi. Berkaitan dengan kompetensi untuk berbicara, mendengarkan orang lain, melaksanakan komunikasi verbal dan non verbal. Kompetensi ini berhubungan dengan segala sesuatu yang berkaitan dengan komunikasi.

4. Kompetensi interpersonal. Yang menyangkut tentang empati, persuasi, negosiasi, penyelesaian konflik dan perbedaan.

5. Kompetensi berpikir. Berfikir strategis, analitis, berkomitmen terhadap tindakan.

6. Kompetensi organisasional. Yang berhubungan dengan perencanaan pekerjaan, pengorganisasian sumber daya, pengukuran kemajuan, serta pengambilan resiko yang berkenaan dengan keputusan.

7. Kompetensi SDM. Berkaitan dengan dalam mengembangkan, memotivasi, dan meningkatkan kinerja dan produktivitas kerja SDM.

8. Kompetensi kepemimpinan. Berhubungan dengan kecakapan dan memosisikan diri, pengembangan organisasional, mengelola transisi, membangun visi, serta memberikan arahan kepada pegawai lainnya.

9. Kompetensi pelayanan. Berhunbungan dengan mengidentifikasi dan melayani pelanggan, baik eksternal maupun internal.

10. Kompetensi bisnis. Berkenaan dengan aspek finansial, penciptaan sistem kerja, serta pengambilan keputusan strategis.

11. Kompetensi manajemen individu. Berhubungan dengan memotivasi diri, bertindak dengan percaya diri, serta mengelola pembelajaran diri secara mandiri.

12. Kompetensi teknis. Berkenaan dengan kompetensi dalam mengerjakan tugas kantor, bekerja dengan teknologi dan mesin, serta menyelesaikan tugas dengan baik.

\section{Karakteristik Kompetensi}

Menurut Spancer dan Spancer, 1993, dalam Donni halaman 258, Kompetensi terbentuk dari lima karakteristik, yaitu motif (motive), watak

P.ISSN: 1410-7988 E.ISSN: 2614-123X 
(traits), konsep diri (self concept), pengetahuan (knowledge), dan keterampilan (skill). Kompetensi keterampilan dan pengetahuan cendrung dapat dilihat, karena berada dipermukaan. Kedua kompetensi ini relatif mudah untuk dikembangkan, misalnya melalui pengalaman atau pelatihan. Sedangkan kompetensi konsep diri, watak, dan motif lebih bersifat tersembunyi dan berperan sebagai sumber kepribadian, lebih sulit untuk dikembangkan.masing-masing karakteristik kompetensi tersebut diuraikan sebagai berikut :

1. Motif. Karakteristik motif merupakan gambaran diri pegawai tentang sesuatu yang dipikirkan atau yang diinginkan, dan merupakan dorngan untuk melakukan tindakan guna memenuhi keinginannya.

2. Watak. Karakteristik watak merupakan karakteristik mental pegawai dan konsistensi respon terhadap rangsangan, tekanan, situasi, dan informasi. Watak ini menentukan tingkat emosi pegawai dalam merespon rangsangan dan informasi.

3. Konsep Diri. Karakteristik konsep diri merupakan gambaran pegawai tentang sikap, nilai-nilai, dan bayangan diri terhadap pekerjaan, tugas, atau jabatan yang dihadapinya untuk dapat diwujudkannya melalui kerja dan usahanya.

4. Pengetahuan. Karakteristik pengetahuan merupakan kemampuan pegawai yang terbentuk dari informasi yang diterima. Pengetahuan yang dimiliki oleh seseorang memprediksi apa yang dapat mereka lakukan, dan bukan apa yang akan mereka lakukan.

5. Keterampilan. Karakteristik keterampilan merupakan kemampuan pegawai untuk melakukan tugas fisik atau mental.

Kompetensi motif, watak, dan konsep diri mempengaruhi tindakan perilaku keterampilan yang pada gilirannya akan mepengaruhi outcame kinerja. Karena itu, dalam kompetensi selalu ada niat, yaitu kekuatan motif dan watak yang menyebabkan terjadinya tindakan yang menghasilkan outcame. Pegawai yang berkompeten dan professional harus mampu menunjukkan karakteristik berupa

1. Mampu mengemban tugas dan pekerjaan yang ada di dalam organisasi secara rasional;

2. Memiliki pengetahuan yang mendalam tentang tugas dan pekerjaan yang diembannya;

3. Menguasai teknik-teknik menyelesaikan tugas dan pekerjaannya dengan lebih efektif dan efisien;

4. Memahami standard an prosedur tugas dan pekerjaan yang ada di dalam organisasi dengan baik;

5. Memiliki daya tahan dan konsistensi yang tinggi dalam mengemban tugas dan pekerjaannya;

6. Memiliki kewenangan yang memancar atas penguasaan perangkat kompetensi yang dalam batas tertentu dapat didemonstrasikan dan teruji, sehingga memungkinkan memperoleh pengakuan dari pihak berwenang.

7. Menjadi dan memiliki relasi yang tergabung dalam organisasi profesi;

8. Berorientasi pada proses dan hasil yang saling mendukung sehingga tugas dan pekerjaan yang diembannyalebih optimal.

\section{Faktor yang mempengaruhi kompetensi}

Pembahasan selanjutnya yang terkait dengan kompetensi adalah seputar permasalahan bisa atau tidak kompetensi seseorang dapat ditingkatkan atau diperbaiki. Menurut Zweel dalam Sudarmanto, (2014: 54) terdapat 7 (tujuh) derterminan yang memengaruhi atau membentuk kompetensi yaitu:

1. Kepercayaan dan nilai seseorang terhadap sesuatu sangat berpengaruh 
terhadap sikap dan perilaku seseorang.

2. Keahlian/ keterampilan, spek ini memegang peranan sangat penting dalam membentuk kompetensi.

3. Pengalaman merupakan elemen penting dalam membentuk penguasaan kompetensi seseorang terhadap tugas.

4. Karakteristik personal seseorang turut berpengaruh terhadap kompetensi seseorang.

5. Motivasi seseorang terhadap suatu pekerjaan atau aktivitas akan berpengaruh terhadap hasil yang dicapai.

6. Isu-isu emosional hambatan dan blok-blok emosional sering kali dapat membatasi penguasaan kompetensi.

7. Kapasitas intelektual seseorang akan berpengaruh terhadap penguasaan kompetensi.

\section{Manfaat Kompetensi}

Ruky dalam Sutrisno (2011: 208) mengemukakan konsep kompetensi memiliki dampak serta manfaat bagi perusahaan sebagi berikut ;

1. Memperjelas standar kerja dan harapan yang ingin dicapai.

Dalam hal ini akan mampu menjawab dua pertanyaan mendasar ; keterampilan, pengetahuan, dan karakteristik apa saja yang dibutuhkan dalam pekerjaan, dan perilaku apa saja yang berpengaruh langsung dengan prestasi kerja.

2. Alat seleksi karyawan.

Membantu organisasi untuk memilih calon karyawan yang terbaik.

3. Memaksimalkan produktifitas.

Tuntutan untuk menjadikan suatu organisasi "ramping" mengahruskan kita untuk mencari karyawan yang dapat dikembangkan secara terarah untuk menutupi kesenjangan dalam keterampilannya.

4. Dasar untuk pengembangan sistem remunerasi.

Dapat mengembangkan sistem remunerasi (imbalan) yang akan dianggap lebih adil.

Eko dan Bisnis (Riau Economics and Business Reviewe) Volume 11, Nomor 3, 27 September 2020
5. Memudahkan adaptasi terhadap perubahan.

Dalam era perubahan yang sangat cepat, sifat dari suatu pekerjaan sangat cepat berubah dan kebutuhan akan kemampuan bar uterus meningkat.

6. Menyelaraskan perilaku kerja dengan nilai- nilai organisasi.

Merupakan cara yang paling mudah untuk mengkomunikasikan nilai- nilai dan hal apa saja yang harus menjadi fokus dalam unjuk kerja karyawan.

\section{Indikator Kompetensi}

Menurut Edison, Anwar, dan Komariah dalam Teguh (2018: 226) untuk memenuhi unsur kompetensi, seseorang pegawai harus memenuhi unsur - unsur yang menjadi indikator dari kompetensi itu sendiri, yakni:

1. Pengetahuan (knowledge). Memiliki pengetahuan yang didapat dari belajar secara formal dan/ atau dari pelatihan- pelatihan atau kursuskursus yang terkait dengan bidang pekerjaan yang ditanganinya.

2. Keahlian (skill). Memiliki keahlian terhadap bidang pekerjaan yang ditanganinya dan mampu menenganinya secara detail. Meski demikian, selain ahli, ia harus memiliki kemampuan (ability) memecahkan masalah dan menyelesaikan sesuatu dengan cepat dan efisien.

3. Sikap (attitude). Menjunjung tinggi etika organisasi, dan memiliki sikap positif (ramah dan sopan) dalam bertindak. Sikap ini tidak bisa dipisahkan dari tugas seseorang dalam melaksanakan pekerjaan dengan benar, dan sikap ini merupakan elemen penting bagi usaha jasa/ pelayanan, bahkan memiliki pengaruh terhadap citra perusahaan/ organisasi.

\section{Kinerja}

\section{Pengertian Kinerja}

Sedarmayanti (2017: 283) arti kata kinerja/ performance merupakan kata benda

$$
\text { P.ISSN: 1410-7988 E.ISSN: 2614-123X }
$$


(noun) di mana salah satu arti adalah "thing done" (sesuatu hasil yang telah dikerjakan, yang berarti :

1. Perbuatan, pelaksanaan pekerjaan, prestasi kerja, pelaksanaan pekerjaan yang berdaya guna.

2. Pencapaian/ prestasi seseorang berkenaan dengan tugas yang diberikan kepadanya.

3. Hasil kerja seseorang pekerja, sebuah proses manajemen atau suatu organisasi secara keseluruhan, dimana hasil kerja tersebut harus dapat ditunjukkan buktinya secara konkrit dan dapat diukur (dibandingkan dengan standar yang telah ditentukan).

4. Sebagai catatan mengenai out-come yang dihasilkan dari suatu aktifitas tertentu selama kurun waktu tertentu pula.

5. Hasil kerja yang telah dicapai oleh seseorang atau sekelompok orang dalam suatu organisasi, sesuai dengan wewenang dan tanggung jawab masing- masing, dalam rangka mencapai tujuan organisasi bersangkutan secara legal, tidak melanggar hukum dan sesuai dengan moral maupun etika.

Kinerja pegawai pada dasarnya merupakan kesediaan seseorang atau sekelompok individu dalam melakukan sesuatu kegiatan dan menyempurnakannya sesuai dengan wewenang dan tanggung jawab dengan hasil seperti yang diharapkan, dan membandingkan hasil kerja yang dicapai oleh para pegawai dengan standar yang telah ditentukan, (Nurmansyah, 2016: 204).

Nurmansyah (2018: 98) kinerja adalah hasil yang dapat dicapai seorang karyawan dalam melaksanakan pekerjaan yang dibebankan kepadanya sesuai dengan wewenang dan tanggung jawab yang diberikan pada satu periode tertentu.

Kinerja seseorang merupakan kombinasi dari kemampuan, usaha dan kesempatan yang dapat dinilai dari hasil kerjanya. Secara defenitif menurut Bernadin \& Russell menjelaskan kinerja merupakan

Eko dan Bisnis (Riau Economics and Business Reviewe) Volume 11, Nomor 3, 27 September 2020 catatan outcome yang dihasilkan dari fungsi pegawai tertentu atau kegiatan yang dilakukan selama periode waktu tertentu, (Sulistiyani dan Rosidah, 2018: 111).

$$
\text { Mangkunegara (2017: }
$$

pengertian kinerja (prestasi kerja) adalah hasil kerja secara kualitas dan kuantitas yang dicapai oleh seorang pegawai dalam melaksanakan tugasnya sesuai dengan tanggung jawab yang diberikan kepadanya.

Menurut Mathis dan Jackson dalam Priansa (2016: 269) kinerja pada dasarnya adalah apa yang dilakukan atau tidak dilakukan oleh pegawai dalam mengemban pekerjaannya.

Kasmir (2016: 182) kinerja merupakan hasil kerja dan perilaku kerja yang telah dicapai dalam menyelesaikan tugas- tugas dan tanggung jawab yang diberikan dalam suatu periode tertentu.

\section{Penilaian Kinerja}

Menurut Dessler, Gary dalam Sedarmayanti (2017: 284) penilaian kinerja adalah prosedur apa saja yang meliputi :

1. Penetapan standar kinerja.

2. Penilaian kinerja actual karyawan dalam hubungan dengan standar.

3. Member umpan balik kepada karyawan dengan tujuan memotivasi karyawan untuk menghilangkan penurunan kinerja atau terus bekerja lebih giat.

Menurut Davis dalam Kasmir (2016: 185) penilaian kinerja merupakan suatu proses dimana organisasi mengevaluasi hasil kinerja individu karyawan.

Busro, (2018: 95) penilaian kinerja (performance appraisal) adalah suatu cara yang dilakukan untuk menilai prestasi kerja seorang pegawai apakah mencapai target pekerjaan yang dibebankan kepadanya.

Widodo (2015: 136) penilaian kinerja adalah proses menilai hasil karya personel dalam suatu organisasi melalui instrument penilaian kinerja. Pada hakikatnya penilaian kinerja merupakan suatu evaluasi terhadap penampilan kerja

P.ISSN: 1410-7988 E.ISSN: 2614-123X 
personel dengan membandingkannya dengan standar baku penampilan.

Yoder (1981) dalam Priansa (2016: 272) penilaian kinerja merupakan prosedur formal yang dilakukan dalam organisasi untuk mengevaluasi pegawai dan kontribusi/ sumbangan serta kepentingan bagi pegawai.

\section{Tujuan dan Manfaat Penilaian Kinerja}

Sulistiyani dan Rosidah, (2018: 327) adapun sejumlah tujuan penilaian kinerja adalah :

1. Untuk mengetahui tujuan dan sasaran manajemen dan pegawai.

2. Memotivasi pegawai untuk memperbaiki kinerjanya.

3. Mendistribusikan reward dari organisasi/ instansi yang dapat berupa pertambahan gaji/ upah dan promosinya yang adil.

4. Mengadakan penelitian manajemen personalia.

Dilihat dari tujuan yang ingin dicapai melalui penilian kinerja tersebut tentu memiliki manfaat bagi orgaisasi diantaranya :

1. Penyesuaian-penyesuaian kompensasi.

2. Perbaikan kinerja.

3. Kebutuhan latihan dan pengembangan.

4. Pengambilan keputusan dalam hal penempatan promosi, mutasi, pemecatan, pemberhentian dan perencanaan tenaga kerja.

5. Untuk kepentingan penelitian kepegawaian.

6. Membantu diagnosis terhadap kesalahan disain pegawai.

Priansa (2016: 272) menyatakan bahwa tujuan penilaian kinerja pegawai adalah untuk kepentingan :

1. Tujuan Evaluasi. Hasil- hasil penilaian kinerja pegawai berfungsi sebagai dasar evaluasi rutin terhadap kinerja pegawai.

1) Penilaian kinerja dan kompensasi tambahan

Penilaian kinerja pegawai akan memberikan masukan bagi keputusan kompensasi dan pendapatan lainnya yang diperoleh pegawai dari organisai.
2) Penilaian kinerja dan kesempatan promosi

Penilaian kinerja pegawai akan memberikan masukan bagi penyusunan tahapan kenaikan jabatan atau kedudukan, pemindahan, bahkan pemberian sanksi bagi pegawai.

2. Tujuan Pengembangan. Informasi yang dihasilkan oleh system penilaian kinerja pegawai dapat dimanfaatkan untuk memudahkan pengembangan pegawai.

1) Mengukuhkan dan menunjang kinerja

Menggunakan penilaian kinerja pegawai sebagai instrument dasar bagi pengembangan pegawai dengan menempatkan manejer dalam peran pengukuhan dan penunjang kinerjanya.

2) Meningkatkan kinerja

Penilaian kinerja pegawai bertujuan untuk meningkatkan kinerja pegawai saat ini serta mencakup pemberian pedoman kepada pegawai untuk meningkatkan kinerjanya dimasa yang akan datang.

3) Menetukan tujuan progresi karir

Penilaian kinerja pegawai memberikan kesempatan kepada manejer dan pegawai untuk membahas rencana karir jangka panjang bagi pegawai.

4) Menentukan kebutuhan pelatihan Hasil penilaian kinerja pegawai dapat dipergunakan untuk kepentingan analisis kebutuhan pelatihan bagi pegawai.

5) Proses yang terkoordinasi

Penilaian kinerja pegawai tidak boleh menjadi proses yang berdiri sendiri, harus terkait dengan aktivitas kepegawaian lainnya agar menjadi efektif dan efisien. 


\section{Faktor-Faktor yang Mempengaruhi Kinerja}

Kasmir (2016: 189) faktor- faktor yang mempengaruhi kinerja baik hasil maupun perilaku kerja adalah sebagai berikut

1. Kemampuan dan keahlian. Merupakan kemampuan atau skill yang dimiliki seseorang dalam melakukan suatu pekerjaan.

2. Pengetahuan. Seseorang yang memiliki pengetahuan tentang pekerjaan secara baik akan memberikan hasil pekerjaan yang baik, demikian pula sebaliknya.

3. Rancangan kerja. Artinya, jika suatu pekerjaan memiliki rancangan yang baik, amak akan memudahkan untuk menjalankan pekerjaan tersebut secara tepat dan benar.

4. Kepribadian. Kepribadian seseorang atau karakter yang dimiliki seseorang, ini menjelaskan bahwa jika seseorang memiliki kepribadian atau karakter yang baik, akan dapat melakukan pekerjaan secara bersungguhsungguh penuh dengan tanggung jawab sehingga hasil pekerjaannya baik.

5. Motivasi kerja. Merupakan dorongan bagi seseorang untuk melakukan pekerjaan. Jika karyawan memiliki dorongan yang kuat dari dalam dirinya atau dari luar dirinya, maka karyawan akan terangsang atau terdorong untuk melakukan sesuatu dengan baik.

6. Kepemimpinan. Merupakan perilaku seorang pemimpin dalam mengatur, mengelola, dan memerintah bawahan untuk mengerjakan sesuatu tugas dan tanggung jawab yang diberikannya.

7. Gaya kepemimpinan. Merupakan gaya atau sikap seorang pemimpin dalam menghadapi atau memerintahkan bawahannya.

8. Budaya organisasi. Merupakan kebiasaan- kebiasaan atau normanorma yang berlaku dan dimiliki oleh suatu organisasi atau perusahaan.

Eko dan Bisnis (Riau Economics and Business Reviewe) Volume 11, Nomor 3, 27 September 2020
9. Kepuasan kerja. Merupakan perasaan senang atau gembira, atau perasaan suka seseorang sebelum dan setelah melakukan suatu pekerjaan.

10. Lingkungan Kerja. Merupakan suasana ataukondisi disekitar lokasi tempat bekerja. Lingkungan kerja dapat berupa ruangan, lay out, sarana dan prasarana, serta hubungan kerja dengan sesame rekan kerja.

11. Loyalitas. Kesetiaan karyawan untuk tetap bekerja dan membela perusahaan di mana tempatnya bekerja.

12. Komitmen. Merupakan kepatuhan karyawan untuk menjalankan kebijakan atau peraturan perusahaan dalam bekerja.

13. Disiplin kerja. Merupakan suatu usaha karyawan untuk menjalankan aktivitas kerjanya secara sungguhsungguh.

\section{Indikator Kinerja}

Menurut Sudarmanto dalam Teguh (2018: 227) mengemukakan 4 dimensi atau indikator yang dapat dijadikan sebagai tolak ukur dalam menilai Kinerja yaitu :

1. Kualitas, Tingkat kesalahan, Kerusakan, Kecermatan

2. Kuantitas, Jumlah pekerjaan yang dihasilkan

3. Penggunaan Waktu dalam bekerja, Tingkat ketidak hadiran, Keterlambatan, waktu kerja efektif/ jam kerja hilang

4. Kerjasama dengan orang lain dalam bekerja.

\section{Pengaruh Kompetensi Terhadap Kinerja}

Dalam hasil penelitian Teguh (2018:

229) disimpulkan bahwa kompetensi berpengaruh positif dan signifikan terhadap kinerja Pegawai Biro Administrasi Perekonomian dan Sumber Daya Alam Sekretariat Daerah Provinsi Riau.

Sedarmayanti (2017: 151) kompetensi merupakan faktor kunci penentu bagi 
seseorang dalam menghasilkan kinerja yang sangat baik. Dalam situasi kolektif, kompetensi merupakan faktor kunci penentu keberhasilan organisasi

\section{METODE}

\section{Lokasi Penelitian}

Penelitian ini dilaksanakan pada Dinas Kesehatan Pekanbaru yang beralamatkan di Jalan Melur No. 103 Kelurahan Harjosari Kecamatan Sukajadi Pekanbaru.

\section{Jenis dan Sumber Data}

Sujarweni (2014: 73) sumber data adalah subjek dari mana asal data penelitian itu diperoleh. Berdasarkan sumbernya data dibagi menjadi ;

\section{Data Primer}

Data primer adalah data yang diperoleh dari responden melalui kuesioner, kelompok fokus, dan panel, atau juga data hasil wawancara peneliti dengan nara sumber. Data yang diperoleh dari data primer ini harus diolah lagi.

\section{Data Skunder}

Data skunder yaitu data yang didapat dari catatan, buku, majalah berupa laporan keuangan publikasi perusahaan, laporan pemerintah, artikel, buku-buku sebagai teori, majalah dan lain sebagainya.

\section{Populasi}

Sugiyono (2016: 80) populasi adalah wilayah generalisasi yang terdiri atas objek/ subjek yang mempunyai kualitas dan karakteristik tertentu yang ditetapkan oleh peneliti untuk dipelajari kemudian ditarik kesimpulannya. Populasi dalam penelitian ini adalah seluruh Pegawai Negeri Sipil yang berada di Dinas Kesehatan Kota Pekanbaru yang berjumlah 92 orang.

\section{Sampel}

Menurut Sugiyono (2016: 81), sampel adalah bagian dari jumlah dan karakteristik yang dimiliki oleh populasi tersebut, dikarenakan populasi kecil maka seluruh populasi dijadikan sampel. Maka sampel yang digunakan dalam penelitian ini berjumlah 91

Eko dan Bisnis (Riau Economics and Business Reviewe) Volume 11, Nomor 3, 27 September 2020 orang, dan 1 orang tidak termasuk sebagai sampel karena juga sebagai pegawai pada Dinas Kesehatan Kota Pekanbaru. Teknik pengambilan sampel dengan menggunakan sampling jenuh adalah teknik penentuan sampel bila semua anggota populasi dijadikan sampel.

\section{Analisa Data}

Analisis data dapat diartikan sebagai upaya data yang sudah tersedia kemudian diolah dengan statistik dan dapat digunakan untuk menjawab rumusan masalah dalam penelitian, (Sujarweni, 2014: 103). Dalam penelitian ini, penulis menggunakan metode

\section{Deskriptif}

Menurut Sugiyono (2016: 147) deskriptif adalah digunakan untuk menganalisis data dengan cara mendeskripsikan atau menggambarkan data yang telah terkumpul sebagaimana adanya tanpa bermaksud membuat kesimpulan yang berlaku untuk umum atau generalisasi.

\section{Kuantitatif}

Merupakan data penelitian yang berasal dari angka-angka dan analisa menggunakan statistik, Sugiyono (2008: 7). Kemudian untuk mengetahui rata-rata jawaban responden digunakan interval kelas

\section{HASIL}

\section{Uji Validitas.}

Validitas digunakan untuk menguji pernyataan satu dengan yang lainnya valid atau tidak. Penyebaran kuesioner dilakukan pada 91 orang responden. Berikut adalah hasil uji validitas instrumen pada tiap- tiap variebel dengan menggunakan program SPSS V.17.0

\section{Tabel 5 Uji Validitas Variabel} Kompetensi

\begin{tabular}{|c|c|c|c|c|}
\hline $\begin{array}{c}\text { No. } \\
\text { Pernyataan }\end{array}$ & rhitung & rtabel & Keterangan & Kesimpulan \\
\hline Pernyataan 1 & 0.699 & 0.206 & $r_{\text {hitung }}>\mathrm{r}_{\text {tabel }}$ & Valid \\
\hline Pernyataan 2 & 0.689 & 0.206 & I $_{\text {hitung }}>\mathrm{r}_{\text {tabel }}$ & Valid \\
\hline Pernyataan 3 & 0.737 & 0.206 & rhitung $>$ Itabel & Valid \\
\hline Pernyataan 4 & 0.742 & 0.206 & rhitung $>\mathrm{r}_{\text {tabel }}$ & Valid \\
\hline Pernyataan 5 & 0.471 & 0.206 & $\mathrm{r}_{\text {hitung }}>\mathrm{r}_{\text {tabel }}$ & Valid \\
\hline Pernyataan 6 & 0.623 & 0.206 & 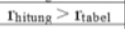 & Valid \\
\hline Pernyataan 7 & 0.613 & 0.206 & $\mathrm{r}_{\text {hitung }}>\mathrm{r}_{\text {tabel }}$ & Valid \\
\hline Pernyataan 8 & 0.687 & 0.206 & $r_{\text {hitung }}>\mathrm{r}_{\text {tabel }}$ & Valid \\
\hline Pernyataan 9 & 0.470 & 0.206 & $r_{\text {hitung }}>\mathrm{r}_{\text {tabel }}$ & Valid \\
\hline
\end{tabular}

Pada tabel 5 diatas, item akan dinyatakan

P.ISSN: 1410-7988 E.ISSN: 2614-123X 
valid jika memiliki nilai $r_{\text {hitung }}>r_{\text {tabel }}$. Nilai $\mathrm{r}_{\text {hitung }}$ dilihat pada kolom $\mathrm{r}_{\text {hitung }}$ yang diperoleh dari olahan data spss. Hasil uji dengan SPSS menunjukkan seluruh item pernyataan variabel kompetensi memiliki nilai $\mathrm{r}_{\text {hitung }}>$ $r_{\text {tabel }}$ (0.206). Maka dapat disimpulkan bahwa seluruh item pernyataan variabel kompetensi dinyatakan valid.

Tabel 6 Uji Validitas Variabel Kinerja

\begin{tabular}{|c|c|c|c|c|}
\hline $\begin{array}{c}\text { No. } \\
\text { Pernyataan }\end{array}$ & $\mathbf{r}_{\text {hitung }}$ & $\mathbf{r}_{\text {tabel }}$ & Keterangan & Kesimpulan \\
\hline Pernyataan 1 & 0.787 & 0.206 & $\mathrm{l}_{\text {hitung }}>\mathrm{r}_{\text {tabel }}$ & Valid \\
\hline Pernyataan 2 & 0.757 & 0.206 & $\mathrm{l}_{\text {hitung }}>\mathrm{r}_{\text {tabel }}$ & Valid \\
\hline Pernyataan 3 & 0.777 & 0.206 & $\mathrm{r}_{\text {hitung }}>\mathrm{r}_{\text {tabel }}$ & Valid \\
\hline Pernyataan 4 & 0.848 & 0.206 & $\mathrm{r}_{\text {hitung }}>\mathrm{r}_{\text {tabel }}$ & Valid \\
\hline Pernyataan 5 & 0.744 & 0.206 & $\mathrm{r}_{\text {hitung }}>\mathrm{r}_{\text {tabel }}$ & Valid \\
\hline Pernyataan 6 & 0.741 & 0.206 & $\mathrm{r}_{\text {hitung }}>\mathrm{r}_{\text {tabel }}$ & Valid \\
\hline Pernyataan 7 & 0.560 & 0.206 & $\mathrm{r}_{\text {hitung }}>\mathrm{r}_{\text {tabel }}$ & Valid \\
\hline Pernyataan 8 & 0.719 & 0.206 & $\mathrm{r}_{\text {hitung }}>\mathrm{r}_{\text {tabel }}$ & Valid \\
\hline Pernyataan 9 & 0.229 & 0.206 & $\mathrm{r}_{\text {hitung }}>\mathrm{r}_{\text {tabel }}$ & Valid \\
\hline Pernyataan 10 & 0.447 & 0.206 & $\mathrm{r}_{\text {hitung }}>\mathrm{r}_{\text {tabel }}$ & Valid \\
\hline
\end{tabular}

Pada tabel 6 diatas, item akan dinyatakan valid jika memiliki nilai $\mathrm{r}_{\text {hitung }}>$ $r_{\text {tabel. }}$. Nilai $r_{\text {hitung dilihat pada kolom } r_{\text {hitung }}}$ yang diperoleh dari olahan data spss. Hasil uji dengan SPSS menunjukkan seluruh item pernyataan variabel kinerja memiliki nilai $r_{\text {hitung }}>r_{\text {tabel }}(0.206)$. Maka dapat disimpulkan bahwa seluruh item pernyataan variabel kinerja dinyatakan valid.

\section{Uji Reliabilitas}

Reliabilitas dapat diartikan sebagai keterandalan atau dapat dipercaya. Instrumen yang reliabel berarti instrumen tersebut jika digunakan beberapa kali untuk mengukur objek yang sama, akan menghasilkan data yang sama. Nilai reliabilitas terdapat pada kolom Cronbach's Alpha, yaitu suatu variabel dianggap reliabel jika nilai cronbach alpha diatas 0.60. Hasil pengujian reliabilitas angket adalah sebagai berikut

\section{Tabel 7 Uji Reliabilitas}

\begin{tabular}{|l|c|c|c|}
\hline \multicolumn{1}{|c|}{ Variabel } & $\begin{array}{c}\text { Cronbach's } \\
\text { Alpha }\end{array}$ & $\begin{array}{c}\text { Nilai } \\
\text { Reliabel }\end{array}$ & Keterangan \\
\hline Kompetensi & 0.817 & 0.60 & Reliabel \\
\hline Kinerja & 0.867 & 0.60 & Reliabel \\
\hline
\end{tabular}

Sumber : Data olahan hasil penelitian SPSS, 2019

Dari tabel 7 dapat dilihat bahwa Cronbach's Alpha pada masing- masing variabel yaitu kompetensi (0.817), dan Eko dan Bisnis (Riau Economics and Business Reviewe) Volume 11, Nomor 3, 27 September 2020 variabel kinerja (0.867) memiliki nilai Cronbach's Alpha diatas 0.60. Artinya bahwa setiap item variabel yang digunakan dalam penelitian ini memiliki kehandalan atau reliabel.

\section{Uji Regresi Linier Sederhana}

Berikut hasil olahan data SPSS pada uji regresi linier sederhana yang dapat dilihat pada tabel berikut :

Tabel 8 Uji Regresi Linier Sederhana

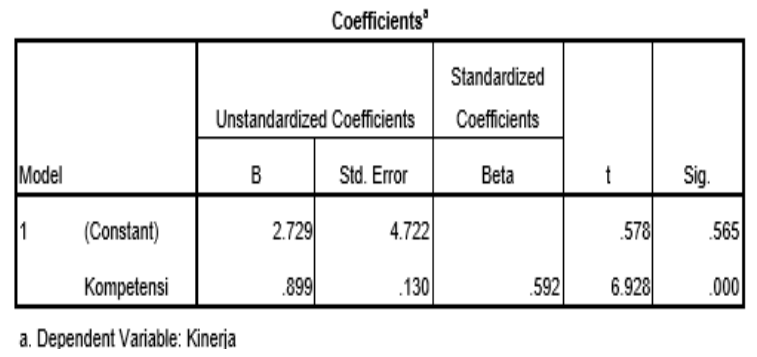

Berdasarkan hasil dari pengolahan data yang disajikan pada tabel 5.29 diatas, maka didapat persamaan regresi linier sederhana sebagai berikut :

$\mathrm{Y}=\mathrm{a}+\mathrm{bX}$ dimana

$\mathrm{Y}=2.729+0.899 \mathrm{X}$

Persamaan regresi tersebut dapat dijelaskan sebagai berikut :

Nilai konstanta $(a)=2.729$ dan nilai koefisien regresi (b) $=0.899$. ini menyatakan bahwa jika kompetensi dianggap konstan maka kinerja adalah sebesar 0.899. Artinya jika kompetensi mengalami kenaikan sebesar 1 satuan, maka kinerja akan mengalami kenaikan sebesar 0.899 .

\section{Uji Hipotesis Distribusi t (Uji t)}

Berikut hasil pengujian uji hipotesis pada uji $\mathrm{t}$ dengan membandingkan anatara nilai $t_{\text {hitung }}$ dengan nilai $t_{\text {tabel }}$

Pada tabel 8 dapat dijelaskan bahwa nilai $\mathrm{t}$ tabel dilihat pada tabel $\mathrm{t}$ dengan df $\mathrm{n}-\mathrm{k}-1$; 91-1-1= 89, sehingga diperoleh nilai $\mathrm{t}_{\text {tabel }}(1.986)$ dan nilai $\mathrm{t}_{\text {hitung }}(6.928)$. Maka dari tabel diatas dapat dijelaskan bahwa dikarenakan nilai $t_{\text {hitung }}$ (6.928) lebih besar dari nilai $t_{\text {tabel }}$ (1.986) dengan tingkat signifikansi $0.000<0.05$. Sehingga dapat disimpulkan bahwa kompetensi berpengaruh signifikan terhadap kinerja pegawai pada Dinas Kesehatan Kota

P.ISSN: 1410-7988 E.ISSN: 2614-123X 
Pekanbaru.

\section{Koefisien determinasi $\left(\mathbf{R}^{2}\right)$}

Koefisien determinasi $\left(\mathrm{R}^{2}\right)$ digunakan untuk mengetahui besarnya persentase sumbangan atau kontribusi variabel bebas analisa jabatan terhadap variabel terikat kinerja. Hasil koefisien determinasi dapat kita lihat pada tabel dibawah ini :

Tabel 9 Koefisien determinasi $\left(\mathbf{R}^{2}\right)$

\begin{tabular}{l|c|c|c|c|}
\hline Model & $\mathrm{R}$ & $\mathrm{R}$ Square & $\begin{array}{c}\text { Adjusted R } \\
\text { Square }\end{array}$ & $\begin{array}{c}\text { Std. Error of the } \\
\text { Estimate }\end{array}$ \\
\hline 1 & $.592^{\mathrm{a}}$ & .350 & .343 & 4.100 \\
\hline
\end{tabular}
a. Predictors: (Constant), Kompetensi
b. Dependent Variable: Kinerja
Sumber : Data olahan hasil penelitian SPSS, 2019

Dari tabel 9 dapat dilihat bahwa nilai koefisien determinasi $\left(\mathrm{R}^{2}\right)$ sebesar 0.350 artinya sumbangan atau kontribusi besarnya pengaruh variabel kompetensi terhadap variabel kinerja sebesar 0.350 atau $35 \%$ sedangkan sisanya $(100-35=65)$ atau $65 \%$ dipengaruhi oleh variabel lain yang diabaikan atau tidak diteliti dalam penelitian ini

\section{SIMPULAN}

Dari hasil penelitian diatas dapat disimpulkan beberapa kesimpulan yang dapat ditarik, yakni :

1. Hasil uji regresi linier sederhana menunjukkan nilai konstanta (a) = 2.729 dan nilai koefisien regresi $(b)=$ 0.899. ini menyatakan bahwa jika kompetensi dianggap konstan maka kinerja adalah sebesar 0.899. Artinya jika kompetensi mengalami kenaikan sebesar 1 satuan, maka kinerja akan mengalami kenaikan sebesar 0.899 .

2. Berdasarkan pengujian hipotesis dengan menggunakan uji $\mathrm{t}$ secara parsial diperoleh nilai $t_{\text {tabel }}(1.986)$ dan nilai $t_{\text {hitung }}$ (6.928). Maka dari tabel diatas dapat dijelaskan bahwa dikarenakan nilai $t_{\text {hitung }}$ (6.928) lebih besar dari nilai $t_{\text {tabel }}$ (1.986) dengan tingkat signifikansi $0.000<0.05$. Sehingga dapat disimpulkan bahwa kompetensi berpengaruh signifikan terhadap kinerja pegawai pada Dinas Kesehatan Kota Pekanbaru.
Koefisien determinasi $\left(\mathrm{R}^{2}\right)$ sebesar 0.350 artinya sumbangan atau kontribusi besarnya pengaruh variabel kompetensi terhadap variabel kinerja sebesar 0.350 atau $35 \%$ sedangkan sisanya $(100-35=65)$ atau $65 \%$ dipengaruhi oleh variabel lain yang diabaikan atau tidak diteliti dalam penelitian ini.

\section{DAFTAR RUJUKAN}

Arifin, Rois, dan Muhammad, Helmi, 2016, Pengantar Manajemen, EmpatDua, Malang.

Edison, Emron, Anwar, Yohny, dan Komariyah, Imas, 2016, Manajemen Sumber Daya Manusia : Strategi dan Perubahan Dalam Rangka Meningkatkan Kinerja Pegawai dan Organisasi, Cetakan Kesatu, CV. Alfabeta, Bandung.

Feriyanto, Andri, dan Triana, Endang, Shyta, 2015, Pengantar Manajemen (3 In 1) Untuk Mahasiswa dan Umum, Cetakan Pertama, Mediatera, Kebumen.

Ghozali, Imam, 2009, Aplikasi Analisis Multivariate Dengan Program SPSS, Edisi Keempat, Universitas Diponegoro.

Hendra, Teguh, 2018, Pengaruh Kompetensi Terhadap Kinerja Pegawai Biro Administrasi Perekonomian Dan Sumber Daya Alam Sekretariat Daerah Provinsi Riau, jurnal Eko dan Bisnis (Riau Economics and Business Reviewe), Volume 9, Nomor 3, P.ISSN: 14107988 E.ISSN: 2614-123X, STIE Riau.

Kasmir, 2016, Manajemen Sumber Daya Manusia (Teori dan Praktik), Edisi 1, Cetakan ke-2, Rajawali Pers, Jakarta.

Mangkunegara, A.A Anwar Prabu, 2017, Manajemen Sumber Daya Manusia Perusahaan, cetakan 14, PT. Remaja Rosdkarya, Bandung. 
Manullang, M, 2015, Dasar-Dasar Manajemen, Cetakan keduapuluh tiga, Gadjah Mada University Press, Yogyakarta.

Nurmansyah, 2018, Pengantar Manajemen Sumber Daya Manusia (konsep teoripenelitian), Cetakan Keempat, Unilak Press, Pekanbaru.

Nurmansyah, 2016, Perilaku Organisasi (mengelola orang dan organisasi), Cetakan Kedua, Unilak Press, Pekanbaru.

Priansa, Donni, Juni, 2016, Perencanaan \& Pengembangan SDM, Cetakan Kedua, Alfabeta, Bandung.

Supomo. R, 2018, Pengantar Manajemen, Cetakan I, Yrama Widya, Bandung.

Sulistiyani, Ambar Teguh, dan Rosidah, 2018, Manajemen Sumber Daya Manusia Pendekatan Teoretik dan praktik Untuk Organisasi Publik, Cetakan I, Gava Media, Yogyakarta.

Sedarmayanti, 2017, Manajemen Sumber Daya Manusia (Reformasi Birokrasi dan Manajemen Pegawai Negeri Sipil), Edisi Revisi, Cetakan Kesembilan, PT. Refika Aditama, Bandung.

Suwatno, dan Priansa, Donni Juni, 2018, Manajemen SDM Dalam Organisasi Publik dan Bisnis, Cetakan Keenam, Alfabeta, Bandung.

Sutrisno, Edy, 2011, Manajemen Sumber Daya Manusia, Ed-1, Cet-3, Kencana, Jakarta.

Sudarmanto, 2014, Kinerja dan Pengembangan Kompetensi SDM, Cetakan Kedua, Pustaka Pelajar, Yogyakarta.

Subagyo Joko, 2015, Metode Penelitian Dalam Teori dan Praktik, Rineka Cipta, Jakarta.

Sujarweni, Wiratna, V, 2015, Statistik Untuk Bisnis \& Ekonomi, Pustaka baru press, Yogyakarta.

Sujarweni, Wiratna, V, 2014, Metodologi Penelitian, Pustakabarupress. Cet.1. Yogyakarta.

Sugiyono, 2019, Statistika Untuk Penelitian, cetakan ke-30, Alfabeta, Bandung.

Eko dan Bisnis (Riau Economics and Business Reviewe) Volume 11, Nomor 3, 27 September 2020
Sugiyono, 2012, Statistik Untuk Penelitian, Cet Ke-21, CV. Alvabeta, Bandung.

Sugiyono, 2008, Memahami Penelitian Kualitatif, CV. Alfabeta, Bandung.

Sugiyono, 2016, Metode Penelitian Kuantitatif, Kualitatif, dan $R \& D$, cetakan ke-23, Alfabeta, Bandung.

Siswanto, 2015, Pengantar Manajemen, Cetakan Kesebelas, PT. Bumi Aksara, Jakarta.

Umar, Husein, 2011, Metode Riset Perilaku Konsumen Jasa, Ghalia Indonesia, Jakarta.

Widodo, Eko, Suparno, 2015, Manajemen Pengembangan Sumber Daya Manusia, Cetakan II, Pustaka Pelajar, Yogyakarta 